\title{
VBA PROGRAM FEJLESZTÉSE FELADATSOROK DOKUMENTUMAINAK GENERÁLÁSÁRA
}

\author{
Fabulya Zoltán
}

\begin{abstract}
Absztrakt: Az online oktatás során a távoli számonkérés megkövetelte, hogy olyan új technikákat alkalmazzunk, mellyel minimálisra csökkenthetők az ellenörzés korlátozottságából adódó visszaélési lehetőségek. Eltérő feladatsorokkal megoldhatjuk, hogy az egyszerre vizsgázók a megoldásaikat egymással megosztva ne tudjanak érdemtelenül több ponthoz jutni. Viszont nagyszámú vizsgázó esetén manuálisan elkészíteni egyedi feladatsorokat nem lehetséges. Olyan VBA programra nyílt igény, mely egy feladattárból állítja össze a kívánt mennyiségben Word dokumentumként a megoldandó feladatsort. Ehhez fel kellett mérni, hogy a feladattár legalább hány feladatot tartalmazzon, milyen szerkezetü legyen. A dokumentumokat generáló programmal elérhető, hogy minden vizsgázó egyedi feladatsort kapjon, melyek bár tartalmazhatnak közös feladatokat, de ezek száma kellően alacsony szinten tartható a feladattár méretétől függően.
\end{abstract}

\begin{abstract}
In online education, remote accountability has required the use of new techniques to minimize the potential for abuse due to limited control. With different sets of tasks, we can solve it so that the candidates at the same time cannot get unnecessarily more points by sharing their solutions with each other. However, in the case of a large number of candidates, it is not possible to create individual task sets manually. There is a need for a VBA program that compiles the required number of tasks from a task store as a Word document. To do this, it was necessary to assess how many tasks the task store should contain and what its structure should be. The document generation program allows each candidate to receive a unique set of tasks, which, although they may include common tasks, can be kept at a sufficiently low level depending on the size of the task pool.
\end{abstract}

Kulcsszavak: VBA, MS Word, programozás, online vizsgáztatás

Keywords: VBA, MS Word, programming, online examination

\section{Bevezetés}

Az oktatás új kihívásokkal áll szemben a vírus okozta helyzetben. Ez nem csak az oktatás technikáját változtatta meg, hanem a számonkérések módját is. Korábban a vizsgáztatás személyes jelenléttel, ellenörzött körülmények mellett zajlott. Az online oktatás során meg kellett oldani, hogy a vizsgázó otthonában tudjon tudásáról számot adni a digitális technika, az internet nyújtotta lehetőségek kihasználásával. Egyenkénti, szóbeli vizsgáztatáskor, webkamera használatával a legegyszerübb a visszaélések megakadályozása. Viszont írásbeli számonkéréskor a kamerás ellenőrzés csak korlátozottan alkalmazható, különösen akkor, amikor egyszerre nagy létszámban van erre szükség. A vizsgázók leleményessége minden képzeletünket felül tudja múlni, amikor tanulás és tudás nélkül szeretnék a követelményeket teljesíteni. Ha ugyanazt a feladatsort oldják meg az egyszerre résztvevők, akkor egyszerüen továbbíthatnák egymásnak a megoldást. Emiatt elsődleges fontosságú, hogy egyedi feladatsorokat készítsünk minden vizsgázó számára. Viszont ezek manuális elkészítésre csak korlátozott mennyiségben van lehetőségünk. Emiatt vált szükségessé a feladatsorok dokumentumainak automatizált előállíthatósága, melyhez jól megtervezett elökészületek után, program írásával nyílik módunk. Az MS Office programcsomag a Visual Basix for Applications (VBA) szolgáltatással 
biztosítja a programozási lehetőséget. Az elkészülő programmal Word dokumentumokat tudunk generálni a szükséges mennyiségben. Így minden vizsgázónak csak a saját feladatsorát tartalmazó Word dokumentum kerül elküldésre. Természetesen most sem biztosíthatjuk, hogy kijátsszák a rendszert, de komoly lépést tehetünk a visszaélések korlátozására az egyedi feladatsorokkal.

\section{Anyag és módszer}

A munka végeredményeként generált feladatsorok Word dokumentumokként adódnak. Az MS Office 2010 programcsomag biztosít minden szükséges eszközt:

- Feladattár kialakítása Word dokumentumként.

- VBA program fejlesztése.

A VBA programozási környezet biztosítja, hogy a monoton ismétlődő feladatok végrehajtását programmal tudjuk megvalósítani (Zimmerman, 1996). Leggyakrabban az Excel táblázatkezelő esetén alkalmaznak VBA programokat (Hampel, 2017 és Hampel, 2018).

Egyszerübb számításokkal meghatározhatjuk, hogy hány feladatból álló feladattárra van szükségünk ahhoz, hogy kellően alacsony legyen két feladatsorban a megegyező feladatok száma. Ehhez a valószínüség-számítás területéröl a Binomiális eloszlású valószínűségi változók eloszlásának (1) és várhatóértékének (2) meghatározására volt szükségünk (Obádovics, 2020).

ahol:

$$
\begin{gathered}
P(X=k)=\left(\begin{array}{l}
n \\
k
\end{array}\right) \cdot p^{k} \cdot(1-p)^{n-k},(k=0, \ldots, n) \\
E(X)=n \cdot p
\end{gathered}
$$

$X$ : valószínűségi változó, két feladatsoron a megegyező feladatok száma

$P(X=k)$ : az esemény valószínűsége

$p$ : az eloszlás paramétere, egy feladat egyezőségének valószínűsége

$n$ : az eloszlás paramétere, egy feladatsoron a feladatok száma

\section{Eredmények és értékelésük}

\subsection{Tervezés}

A feladatsorok generálásához elsőként meg kellett tervezni minden részletet. Elsőként, hogy hány feladatot tartalmazzon egy feladatsor. Ezt a következők befolyásolják:

- A feladattípusok száma.

- A feladatsor megoldására biztosított időtartam.

A fentiek alapján 8 feladat szerepeltetésével elérhető, hogy a feladattípusoknak legalább fele megjelenjen egy feladatsoron, miközben a megoldás időtartama 80 perc. Az időtartam megállapítása több éves oktatói, vizsgáztatói tapasztalatból adódik, mely szerint elegendő a saját megoldás időtartamának kétszeresét biztosítani. Így feladatonként átlagosan 10 perc elegendő a vizsgázóknak. 
A következő kérdés a feladattár mérete. Ez azért fontos, mert több feladatot tartalmazó feladattár esetén kisebb valószínüséggel lesz egyező feladat két olyan feladatsoron, mely a feladattárból véletlenszerü kiválasztásokkal keletkezik. Elegendőnek bizonyult, hogy minden feladat 4 lehetöség egyikeként adódjon. A valószínűség-számítás eszközeit használva binomiális eloszlású valószínűségi változó $(X)$ jelöli két feladatsoron a megegyező feladatok számát, Az eloszlás paramétereinek értéke:

$$
\begin{aligned}
& n=8 \\
& p=\frac{1}{4}
\end{aligned}
$$

Az első paraméter egy feladatsoron a feladatok száma (független kiválasztások száma), míg a második paraméter egy kiválasztott feladat egyezőségének valószínűsége egy másik feladatsor adott sorszámú feladatával. A következő eredmények adódtak:

- Két feladatsor teljes egyezőségének a valószínüsége

$$
P(X=8)=\left(\begin{array}{l}
n \\
k
\end{array}\right) \cdot p^{k} \cdot(1-p)^{n-k}=\left(\begin{array}{l}
8 \\
8
\end{array}\right) \cdot\left(\frac{1}{4}\right)^{8} \cdot\left(1-\frac{1}{4}\right)^{8-8}=\frac{1}{65536}
$$

- Két feladatsoron az egyező feladatok számának várható értéke

$$
E(X)=n \cdot p=8 \cdot \frac{1}{4}=2
$$

Tehát átlagosan 2 feladat lenne egyező a 8 feladatot tartalmazó feladatsorokon. A fenti eredményből az is kiolvasható, hogy 65536 különböző feladatsor állítható össze, melyek legalább egy feladatban eltérnek egymástól.

Ez alapján a feladattár $8 \times 4=32$ feladatot tartalmaz. Viszont ha a 4-4 alternatív feladat azonos típusú lenne, akkor csak 8 feladattípus jelenhetett volna meg a vizsgán. Mivel ennél több (15) feladattípus számonkérése a cél, ezért az egyes típusok fontosságát is figyelembe kellett venni. Hogy a legfontosabb feladattípusok biztosan szerepeljenek egy feladatsoron, belölük 4-4 szükséges a példatárba, míg a kevésbe fontosakból ennél kevesebb.

\subsection{A feladattár szerkezete}

A feladattár 8 csoportban tartalmaz csoportonként 4 feladatot. Minden csoportból 1 feladat kerül be egy feladatsorba. Mivel a feladattár egy Word dokumentum, ezért azt is meg kell oldanunk, hogy a feladatsorokat generáló program értelmezni tudja egy-egy feladat elhelyezkedését a dokumentumban. Ez a legegyszerübben úgy valósítható meg, ha minden feladat egyetlen bekezdést alkot, hiszen a bekezdéseket sorszámukkal képes azonosítani a VBA programnyelve. Viszont a feladatok kiírásakor sokszor lehetetlen a tördelést egyetlen bekezdéssel megvalósítani. Emiatt minden feladat egy-egy szövegdobozban adható meg. Ekkor olyan szerkezetü feladattárat kapunk, mely 32 bekezdésböl áll, s minden bekezdés egy szövegdobozt tartalmaz. A szövegdobozon belül tetszőleges számú bekezdésben kialakíthatjuk egy feladat kiírását. 


\subsection{A feladatsort generáló program}

A generáló program feladata, hogy a kívánt darabszámban hozzon létre feladatsorokat úgy, hogy a feladattár mind a 8 csoportjából egy feladatot véletlenszerüen kiválaszt a négy közül.

A VBA program a következö:

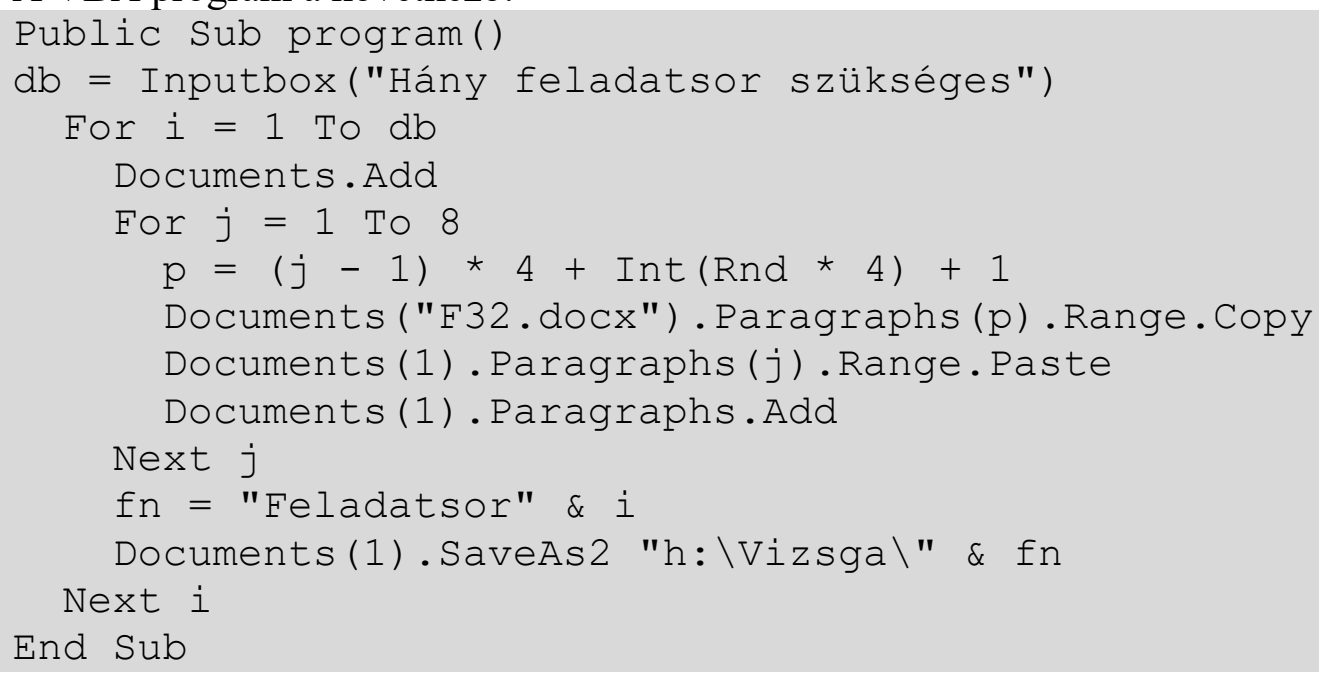

A program elsőként bekéri a db változóba a generálandó feladatsorok darabszámát. Ezt követően a For i ... Next i ciklus biztosítja, hogy egy feladatsor dokumentumát létrehozó utasítások újból végrehajtásra kerüljenek a szükséges számban (db).

Egy feladatsor kialakításának lépései:

- Új dokumentum létrehozása (Documents. Add).

- Mind a 8 csoportból egy feladat kimásolása az új dokumentumba.

- A csoport 4 feladatából az egyiket véletlenszerúen kiválasztani és képezni, hogy ez hányadik bekezdés a feladattárban.

- Vágólapra másolni a kiválasztott bekezdést (Copy).

- Beilleszteni a vágólap tartalmát a generált új dokumentumba (Paste).

○ Újabb bekezdéssel kiegészíteni a generált dokumentumot a következő feladat számára (Paragraphs.Add).

- Fájlnév képzése a mentéshez ( $\mathrm{fn}$ ).

- A generált dokumentum mentése (SaveAs2).

A dokumentumok fájlnevének végén a sorszámuk (i) található, $s$ a fájlok a Vizsga mappában lesznek.

\section{Következtetések}

A Visual Basic for Applications szolgáltatással kis programozói ismeretek birtokában egyszerüen megoldhatjuk, hogy egy feladattár alapján tetszőleges számban generáljunk feladatsorokat. Így elérhetjük, hogy a vírushelyzet okozta 
online oktatás és távoli számonkérés során minden vizsgázó egyedi feladatsort kapjon, hogy egymás segítésének lehetőségét alacsony szinten tudjuk tartani.

\section{Irodalomjegyzék}

Hampel Gy. (2017): Excel VBA alkalmazása egy biometriai esettanulmány példáján bemutatva, Jelenkori társadalmi és gazdasági folyamatok, 12 (4): 35-40.

Hampel Gy. (2018): Egymintás t-próba programozható kialakítása Sxcel VBA környezetben, Jelenkori társadalmi és gazdasági folyamatok, 13 (3-4): 169-175.

Obádovics J. Gy. (2020): Valószinüségszámítás és matematikai statisztika, Scolar Kiadó Kft., Budapest.

Zimmerman M. W. (1996): Microsoft Office 97 Visual Basic Programmer's Guide. MicrosoftPress, Washington. 